\title{
Clinical features and outcomes of infective endocarditis in Egypt: an 11-year experience at a tertiary care facility
}

\author{
Hussein Hassan Rizk', Ahmed Adel Elamragy ${ }^{1 *}$ (D), Ghada Sayed Youssef ${ }^{1}$, Marwa Sayed Meshaal ${ }^{1}$, Ahmad Samir ${ }^{1}$, \\ Ahmed ElSharkawy², Karim Said ${ }^{1}$, Hussien Heshmat Kassem¹, Mervat Gaber Elanany ${ }^{3}$, Amani Ali El-Kholy ${ }^{3}$, \\ Al Sayed Akl2 , Soheir M. Mahfouz ${ }^{4}$ and Khaled Ali Sorour ${ }^{1}$
}

\begin{abstract}
Background: Few data are available on the characteristics of infective endocarditis (IE) cases in Egypt. The aim of this work is to describe the characteristics and outcomes of IE patients and evaluate the temporal changes in IE diagnostic and therapeutic aspects over 11 years.

Results: The IE registry included 398 patients referred to the Endocarditis Unit of a tertiary care facility with the diagnosis of possible or definite IE. Patients were recruited over two periods; period $1(n=237,59.5 \%)$ from February 2005 to December 2011 and period 2 ( $n=161$, 40.5\%) from January 2012 to September 2016. An electronic database was constructed to include information on patients' clinical and microbiological characteristics as well as complications and mortality. The median age was 30 years and rheumatic valvular heart disease was the commonest underlying cardiac disease (34.7\%). Healthcare-associated IE affected 185 patients (46.5\%) and 275 patients (69.1\%) had negative blood cultures. The most common complications were heart failure $(n=148,37.2 \%)$, peripheral embolization ( $n=133,33.4 \%)$, and severe sepsis $(n=100,25.1 \%)$. In-hospital mortality occurred in 108 patients (27.1\%). Period 2 was characterized by a higher prevalence of injection drug use-associated IE (15.5\% vs. $7.2 \%, p=0.008)$, a higher staphylococcal IE (50.0\% vs. $35.7 \%, p=0.038)$, lower complications $(31.1 \%$ vs. $45.1 \%$, $p=0.005)$, and a lower in-hospital mortality (19.9\% vs. $32.1 \%, p=0.007)$.
\end{abstract}

Conclusion: This Egyptian registry showed high rates of culture-negative $\mathrm{IE}$, complications, and in-hospital mortality in a largely young population of patients. Improvements were noted in the rates of complications and mortality in the second half of the reporting period.

Keywords: Endocarditis, Registries, Egypt

\section{Background}

Infective endocarditis (IE) remains an evolving disease with high morbidity and mortality even in the modern era of advanced diagnostic imaging, improved antimicrobial chemotherapy, and potentially curative surgery [1]. Despite these improvements in diagnosis and management, the incidence of the disease is unchanged over the past two decades at approximately 1.7-6.2 cases per 100,000 per year [1] and has not appreciably changed recently.

\footnotetext{
* Correspondence: ahmed.elamragy@kasralainy.edu.eg

${ }^{1}$ Department of Cardiology, Kasr Al Aini Hospital, Faculty of Medicine, Cairo University, Cairo 11562, Egypt

Full list of author information is available at the end of the article
}

Almost all aspects of the disease, including its natural history, risk factors, sequelae, and causative organisms, have changed substantially since Osler's first descriptions in the nineteenth century [2]. In particular, rheumatic heart disease (RHD) is now a less common risk factor, whereas degenerative valve disease in older individuals, mitral valve prolapse, intravenous drug use (IVDU), prosthetic valves, or devices have become the most common reasons for IE, coinciding with an increase in IE caused by staphylococcal infections and some fastidious organisms $[1,3]$. Furthermore, pathogens that were previously difficult to detect and evolving multi-drug-resistant bacteria pose a challenge to the conventional therapeutic armamentarium [2]. 
These changes led to an alteration in IE epidemiology as well as outcomes over the past years. In Egypt, the prevalence of RHD is still high and the use of devices and prosthetic materials is also on the rise. This may put the population at high risk for IE. No national data on the IE burden is available, although it is imperative.

We reviewed all cases of IE referred to a tertiary care facility in Egypt and developed a registry with the goal of describing the clinical features and outcome of patients over a decade. A secondary goal was to describe the temporal trend in the disease outcome based on applying a bundle of interventions.

\section{Methods}

\section{Study design and patient population}

A specialized unit for IE was established in February 2005 in a tertiary care facility. It included cardiologists, cardiothoracic surgeons, laboratorians, radiologists, and pathologists. Data from all patients with possible/definite IE [4] was recorded in a specialized secure electronic database after thorough revision to build a registry which became part of two international multicenter registries: the International Collaboration on Endocarditis Prospective Cohort Study (ICE-PCS) in 2007 and the European Infective Endocarditis registry (EuroENDO registry) in August 2016.

This study involves all patients in the registry between February 2005 and September 2016. Patients' data included demographics, clinical features, comorbid conditions, history, underlying heart disease, recent procedures, and history of IVDU. Early prosthetic valve endocarditis (PVE) was defined as IE that occurred within 1 year of surgical implantation of the prosthesis while IE that occurred afterwards was considered late PVE. Health-care associated IE (HAE) was defined as (1) nosocomial IE: IE occurred $\geq 48 \mathrm{~h}$ after hospital admission.(2) Non-nosocomial IE: IE occurring within (a) 1 month of receiving IV cannulation, chemotherapy, or dialysis; (b) 3 months after admission into an acute care facility; or (c) any time after admission into a nursing home. IVDU-associated IE was diagnosed if the patient reported injection drug use within 3 months of the onset of IE symptoms and was admitted from the community without an alternative risk factor for IE. Blood cultures, serologic tests for antibodies (against Coxiella burnetii, Bartonella, Brucella, and Aspergillus), surgical specimen cultures, and histopathologic examination were performed according to the IE unit protocol (Additional file 1). Transthoracic echocardiography (TTE) was performed within 24-48 h of hospital admission followed by transesophageal echocardiography within another $72 \mathrm{~h}$ if there was a clinical indication. Patients were followed for the duration of their hospital stay till either discharge or death, monitoring for inhospital complications such as heart failure (HF), severe sepsis, intracranial hemorrhage, embolization, pulmonary infarcts, renal failure (defined as serum creatinine > $2 \mathrm{mg} / \mathrm{dl}$ ), aortic root abscess, acute mitral or aortic regurgitation, splenic infarcts and abscesses, mycotic aneurysms, prosthesis-related complications (dehiscence, paravalvular leak, and stuck valve), and death. All patients underwent appropriate diagnostic modalities and received a full course of treatment with antimicrobials and surgical interventions as recommended by the current guidelines [5-11]. Prior to discharge, individual patient education was provided on need for IE prophylaxis, dental care, and symptoms and signs of IE recurrence. In addition to the regular patient care, the IE team in the specialized unit was involved in discussing complicated cases for decisionmaking, organizing seminars, and regular meetings to discuss clinical findings, preparing and distributing brochures about proper IE diagnosis, and management as well as arranging infection control awareness meetings and workshops on proper blood and tissue sampling techniques. Additionally, there were regular internal and external auditing meetings to monitor the progress of the IE registry.

\section{Statistical analysis}

Analysis of data obtained from the database was done using SPSS 20.0 program. Data were expressed in terms of frequency as percentages for categorical variables. Continuous variables were presented as mean \pm standard deviation (SD) if normally distributed or median and interquartile range (IQR) if skewed. Differences in categorical variables were tested by the chi-square test or Fisher's exact (when appropriate). Comparison of means was tested by independent student $t$ test. Significant univariate variables for in-hospital mortality were entered a multivariate binary logistic regression model to detect the most significant independent predictors. Statistical significance was defined as $p$ values of $<0.05$.

\section{Results}

\section{Baseline characteristics}

A total of 398 definite/possible consecutive IE patients were included in the IE registry between February 2005 and September 2016. We divided the registry into two periods according to the enrollment date. Period $1(n=$ $237,59.5 \%$ ) included patients referred to the unit in the first 6 years (between 2005 and December 2011) and period $2(n=161,40.5 \%)$ included patients referred between January 2012 and September 2016. The baseline clinical characteristics of the whole cohort and for each of the two periods are presented in Table 1.

The patients were relatively young (median: 30 years, IQR: $24-39$ years) and the majority were men. The main 
Table 1 Baseline clinical characteristics

\begin{tabular}{|c|c|c|c|c|}
\hline Variable & Total $(n=398)$, No. $(\%)$ & Phase $1(n=237)$, No. $(\%)$ & Phase $2(n=161)$, No. (\%) & $P$ value \\
\hline Gender, male & $243(61.1)$ & $139(58.6)$ & $104(64.6)$ & 0.232 \\
\hline Age, years & $30(24-39)^{a}$ & $29(23-38)^{a}$ & $30(24-40)^{\mathrm{a}}$ & 0.414 \\
\hline Underlying cardiac diseases & $255(64.1)$ & $191(82.3)$ & $64(43.0)$ & $<0.001$ \\
\hline - Rheumatic heart disease & $138(34.7)$ & $94(40.5)$ & $44(29.5)$ & 0.029 \\
\hline - Congenital heart disease & $32(8.0)$ & $24(10.3)$ & $8(5.4)$ & 0.088 \\
\hline - Degenerative valve disease & $10(2.5)$ & $7(3.0)$ & $3(2.0)$ & 0.550 \\
\hline - Floppy valves & $12(3.0)$ & $8(3.4)$ & $4(2.7)$ & 0.463 \\
\hline - Hypertrophic cardiomyopathy & $3(0.8)$ & $3(1.3)$ & $0(0)$ & 0.225 \\
\hline - Prosthetic valves IE & $117(29.4)$ & $70(29.5)$ & $47(29.2)$ & 0.941 \\
\hline - AV mechanical prosthesis & $58(14.6)$ & $32(13.5)$ & $26(16.1)$ & \\
\hline - AV bioprosthesis & $5(1.3)$ & $3(1.3)$ & $2(1.2)$ & \\
\hline - MV mechanical prosthesis & $60(15.1)$ & $39(16.5)$ & $21(13.0)$ & \\
\hline - MV bioprosthesis & $1(0.3)$ & $0(0)$ & $1(0.6)$ & \\
\hline - TV bioprosthesis & $2(0.5)$ & $0(0)$ & $2(1.2)$ & \\
\hline - Pacemaker/ICD ${ }^{\mathrm{b}}$ lead IE & $5(1.3)$ & $2(0.8)$ & $3(1.9)$ & 0.324 \\
\hline - Intravenous drug abuse & $42(10.6)$ & $17(7.2)$ & $25(15.5)$ & 0.008 \\
\hline Healthcare associated IE & $185(46.5)$ & $131(55.3)$ & $54(33.5)$ & $<0.001$ \\
\hline * Hospital admission within the last 3 months & $151(37.9)$ & $104(43.9)$ & $47(29.2)$ & 0.01 \\
\hline * Procedures within the last 3 months & $95(23.9)$ & $71(30.6)$ & $24(16.1)$ & 0.001 \\
\hline - Intravenous line & $37(9.3)$ & $20(8.4)$ & $17(10.6)$ & 0.475 \\
\hline - Early prosthetic valve $\mathrm{IE}^{\mathrm{C}}$ & $27(23.1)$ & $20(28.6)$ & $7(14.9)$ & 0.69 \\
\hline - Hemodialysis & $15(3.8)$ & $10(4.2)$ & $5(3.1)$ & 0.387 \\
\hline - Urinary catheter & $2(0.5)$ & $1(0.4)$ & $1(0.6)$ & 0.646 \\
\hline - Non cardiac surgery & $16(4.0)$ & $9(3.6)$ & $7(4.3)$ & 0.784 \\
\hline - Dental procedure & $9(2.3)$ & $5(2.1)$ & $4(2.5)$ & 0.529 \\
\hline - Abortion/dilation and curettage & $4(1.0)$ & $2(0.8)$ & $2(1.2)$ & 0.231 \\
\hline Fever & $335(84.2)$ & $205(86.5)$ & $130(80.7)$ & 0.123 \\
\hline - Duration of fever, days & $28(13-60)^{a}$ & $21(10-56)^{a}$ & $30(14-60)^{a}$ & 0.010 \\
\hline Previous use of antibiotics & $231(58.0)$ & $171(72.2)$ & $60(37.3)$ & $<0.001$ \\
\hline Prior endocarditis & $15(3.8)$ & $8(3.4)$ & $7(4.3)$ & 0.617 \\
\hline
\end{tabular}

aedian, IQR interquartile range

${ }^{\mathrm{b}} / C D$ implantable cardioverter defibrillator

'Percentages are related to the number of prosthetic valve IE

underlying cardiac disease was RHD. The percent of patients with history of IVDU was significantly higher in period 2 compared to period 1 while there was a significant decrease in those with RHD, HAE, and previous antibiotic use. Of the 185 patients with HAE, 76 (41.1\%) patients had no underlying structural heart diseases [period 1: $n=47(35.9 \%)$ vs. period 2: $n=29$ (53.7\%), $p$ $=0.025]$. The majority reported fever of long duration, which was significantly longer in period 2 .

\section{Echocardiographic findings}

The most pertinent echocardiographic findings are reported in Table 2. TTE was diagnostic in most of the patients (78.9\%). Mitral valve was the most commonly affected valve (37.2\%), followed by the aortic valve (28.6\%). Patients from period 1 had more left-sided valvular involvement while right-sided valvular involvement was more common in period 2 as well as more ring abscesses. TTE was positive in significantly more patients in period 2 .

\section{Microbiologic data}

Microbiological findings and antimicrobials used in treatment of IE are presented in Table 3. Patients from period 2 were significantly more likely to have negative blood cultures, but an organism was more 
Table 2 Echocardiography findings

\begin{tabular}{|c|c|c|c|c|}
\hline Variable & Total $(n=398)$, No. $(\%)$ & Phase $1(n=237)$, No. $(\%)$ & Phase $2(n=161)$, No. $(\%)$ & $P$ value \\
\hline Diagnostic TTE & $314(78.9)$ & $178(75.1)$ & $136(84.5)$ & 0.025 \\
\hline Presence of vegetations & $298(74.9)$ & $175(78.1)$ & $123(76.9)$ & 0.772 \\
\hline - Left sided vegetations & $240(60.3)$ & $154(65.0)$ & $86(53.4)$ & 0.021 \\
\hline - Aortic valve vegetations & $114(28.6)$ & $73(30.8)$ & $41(25.5)$ & $<0.001$ \\
\hline - Mitral valve vegetations & $148(37.2)$ & $85(49.0)$ & $63(39.2)$ & $<0.001$ \\
\hline - Right sided vegetations & $68(17.1)$ & $23(9.7)$ & $45(28.0)$ & $<0.001$ \\
\hline - Pulmonary valve vegetations & $6(1.5)$ & $2(0.8)$ & $4(2.5)$ & $<0.001$ \\
\hline - Tricuspid valve vegetations & $62(15.6)$ & $20(8.4)$ & $42(26.1)$ & $<0.001$ \\
\hline Ring abscess & $52(13.1)$ & $25(12.6)$ & $27(23.7)$ & 0.012 \\
\hline Pericardial effusion & $85(21.4)$ & $53(27.2)$ & $32(24.1)$ & 0.527 \\
\hline - Mild & $73(18.3)$ & $46(19.4)$ & $27(16.8)$ & \\
\hline - Moderate & $8(2.0)$ & $3(1.3)$ & $5(3.1)$ & \\
\hline - Large & $4(1.0)$ & $4(1.7)$ & $0(0)$ & \\
\hline
\end{tabular}

TTE transthoracic echocardiography

likely to be detected in period 2. The most common organisms detected were staphylococcal species; with a significant increase in isolation of staphylococci from period 1 to 2, while there was a significant decrease in diagnosis of zoonotic IE. Fungal infections accounted for $8 \%$ of all cases. The demographic, clinical, and echocardiographic features of this subgroup were previously published [12].

\section{Complications}

Complications and outcomes are shown in Table 4. The overall complication rate (especially HF) decreased significantly from period 1 to 2 while the diagnosis of splenic and pulmonary infarcts increased significantly. Response to medical management was noted in approximately $47 \%$, with surgical indication in $74 \%$ of patients overall and in-hospital mortality of $27 \%$. There was a

Table 3 Microbiological and antimicrobial data

\begin{tabular}{|c|c|c|c|c|}
\hline Variable & Total $(n=398)$, No. $(\%)$ & Phase $1(n=237)$, No. $(\%)$ & Phase $2(n=161)$, No. (\%) & $P$ value \\
\hline Negative blood culture & $275(69.1)$ & $152(64.1)$ & $123(76.4)$ & 0.009 \\
\hline Detected organisms ${ }^{a}$ & $155(38.9)$ & $83(36.4)$ & $72(50.3)$ & 0.008 \\
\hline - Staphylococcal species & $88(22.1)$ & $46(35.7)$ & $42(50.0)$ & 0.038 \\
\hline - Streptococci & $36(9.0)$ & $26(20.2)$ & $10(11.9)$ & 0.116 \\
\hline - Enterococci & $16(4.0)$ & $9(3.8)$ & $7(4.3)$ & 0.991 \\
\hline - Gram-negative bacilli & $32(8.0)$ & $22(17.1)$ & $10(11.9)$ & 0.304 \\
\hline - Zoonoses & $21(5.3)$ & $18(14.0)$ & $3(3.6)$ & 0.009 \\
\hline - Fungal infection ${ }^{c}$ & $32(8.0)$ & $17(7.2)$ & $15(9.3)$ & 0.440 \\
\hline \multicolumn{5}{|l|}{ Basis of choice of antibiotics } \\
\hline - Culture/Serology based & $86(21.6)$ & $42(17.7)$ & $44(27.3)$ & \multirow[t]{3}{*}{0.022} \\
\hline - Empirical & $312(78.4)$ & $195(82.3)$ & $117(72.7)$ & \\
\hline Therapeutic antibiotics used ${ }^{d}$ & $(n=1044)$ & $(n=610)$ & $(n=434)$ & \\
\hline - Anti-Staphylococcal ${ }^{e}$ & $228(21.8)$ & $120(19.7)$ & $108(24.9)$ & 0.045 \\
\hline - Aminoglycosides & $310(29.7)$ & $162(26.6)$ & $148(34.1)$ & 0.009 \\
\hline - Quinolones & $20(1.9)$ & $3(0.5)$ & $17(3.9)$ & $<0.001$ \\
\hline - B-lactam and Cephalosporins & $338(32.4)$ & $233(38.2)$ & $105(24.2)$ & $<0.001$ \\
\hline
\end{tabular}

${ }^{\mathrm{a}}$ Organisms are detected by either blood culture, positive histology or positive serology

bzoonotic infections included: Brucella, Bartonella, and Coxiella

'Fungal infections included: Aspergillus, Candida, Mucormycosis, and Penicillium

${ }^{\mathrm{d}}$ Numbers are calculated according to the total number of antibiotics used

${ }^{\mathrm{e}}$ Anti-Staphylococci included; Vancomycin, Linezolid, and Teicoplanin 
Table 4 Complications of IE

\begin{tabular}{|c|c|c|c|c|}
\hline Variable & Total $(n=398)$, No. $(\%)$ & Phase $1(n=237)$, No. $(\%)$ & Phase $2(n=161)$, No. $(\%)$ & $P$ value \\
\hline Overall complications & $157(39.4)$ & $107(45.1)$ & $50(31.1)$ & 0.005 \\
\hline - Heart failure & $148(37.2)$ & $98(41.4)$ & $50(31.1)$ & 0.011 \\
\hline - Severe sepsis & $100(25.1)$ & $56(23.6)$ & $44(27.3)$ & 0.304 \\
\hline - Renal failure (Creatinine > 2 mg/dl) & $82(20.6)$ & $48(20.2)$ & $34(21.1)$ & 0.941 \\
\hline - Need for dialysis & $18(4.5)$ & $13(5.5)$ & $5(3.1)$ & 0.236 \\
\hline - Acute mitral regurgitation & $37(9.3)$ & $21(8.9)$ & $16(9.9)$ & 0.779 \\
\hline - Papillary muscle rupture & $4(1.0)$ & $2(0.8)$ & $2(1.2)$ & 0.545 \\
\hline - Acute aortic regurgitation & $26(6.5)$ & $14(5.9)$ & $12(7.5)$ & 0.585 \\
\hline - Splenic infarction & $38(9.5)$ & $18(7.6)$ & $20(12.4)$ & 0.123 \\
\hline - Splenic abscess & $19(4.8)$ & $7(3.0)$ & $12(7.5)$ & 0.044 \\
\hline - Pulmonary infarction & $31(7.8)$ & $10(4.2)$ & $21(13.0)$ & 0.001 \\
\hline - Prosthesis-related complications & $33(8.3)$ & $21(8.9)$ & $12(7.5)$ & 0.709 \\
\hline - Dehiscence & $17(4.3)$ & $12(5.1)$ & $5(3.1)$ & \\
\hline - Para-valvular leak & $10(2.5)$ & $5(2.1)$ & $5(3.1)$ & \\
\hline - Stuck valve & $6(1.5)$ & $4(1.7)$ & $2(1.2)$ & \\
\hline - Mycotic aneurysm & $24(6.0)$ & $11(4.6)$ & $13(8.1)$ & 0.167 \\
\hline - Intracranial hemorrhage & $26(6.5)$ & $17(7.4)$ & $9(5.6)$ & 0.481 \\
\hline - Peripheral embolization & $133(33.4)$ & $78(32.9)$ & $55(34.2)$ & 0.941 \\
\hline - CNS embolization & $50(12.6)$ & $34(14.3)$ & $16(9.9)$ & 0.152 \\
\hline \multicolumn{5}{|l|}{ Outcomes } \\
\hline - Response to medical treatment & $185(46.5)$ & $90(38.0)$ & $95(59.0)$ & $<0.001$ \\
\hline - Indication for surgery & $294(73.9)$ & $180(75.9)$ & $114(70.8)$ & 0.252 \\
\hline - Surgery performed & $176(59.9)$ & $113(62.8)$ & $63(55.3)$ & 0.092 \\
\hline - In-hospital mortality & $108(27.1)$ & $76(32.1)$ & $32(19.9)$ & 0.007 \\
\hline
\end{tabular}

significant improvement in response to medical management and a significant decrease in in-hospital mortality noted between period 1 and 2 .

\section{Predictors of in-hospital mortality}

In univariate analysis, predictors included early prosthetic IE, overall complication rate, severe sepsis, intracranial hemorrhage, lack of response to medical therapy, presence of surgical indication, not performing indicated surgery, HAE, and pericardial effusion. A multivariate logistic regression model-that correctly classified $89 \%$ of cases-determined the most significant independent factors associated with increased risk of in-hospital mortality: (1) severe sepsis (OR 23.6, 95\% CI 9.6-58.3, $p<$ 0.001), (2) intracranial hemorrhage (OR 3.5, 95\% CI 1.57.7, p: 0.003), (3) any complications (OR 3.4, 95\% CI $2.2-5.4, p<0.001$ ), (4) early prosthetic valve IE (OR 3.2, 95\% CI 1.4-7.0, p: 0.003), (5) any indication for surgery (OR 3.0, 95\% CI 1.6-5.6, $p<0.001$ ), (6) HAE (OR 2.0, 95\% CI 1.3-3.2, $p$ : 0.003), and (7) underlying heart disease (OR 1.8, 95\% CI 1.1-2.9, p: 0.02).

Factors associated with a decreased in-hospital mortality included (1) response to medical treatment (OR 0.03,
95\% CI 0.01-0.08, $p<0.001$ ), (2) zoonotic infection (OR 0.3 , 95\% CI $0.1-1.2, p$ : 0.05 ), and (3) performing indicated surgery (OR 0.4, 95\% CI 0.3-0.7, $p<0.001$ ).

\section{Discussion}

This is the first published comprehensive report from Egypt on all patients with IE admitted to a tertiary care facility over 11 years. Reports of subgroup analysis were previously published elsewhere [12-18]. In this cohort, we observed certain characteristics that may be particularly relevant to other low-resource countries.

The patient population was relatively young (median 30 years), similar to reports from Lebanon [19] and Saudi Arabia [20] but in contrast to other registries from resource-rich countries such as Italy [21] (median 57 years) and China [22] (mean 43.5 years). This difference is likely due to the difference in underlying heart disease. In Egypt (as in many other low-resource countries), RHD remains a common underlying heart disease followed by prosthetic valves (usually indicated for RHD) while in the resource-rich countries, degenerative heart diseases of the elderly, and increasing use of 
prosthetic devices (valves and pacemakers) are the main underlying etiology.

Another striking feature from our data is the long duration of symptoms (i.e., fever) prior to admission with the diagnosis of IE (median 28 days). This cohort includes patients referred to a tertiary care facility receiving patients from rural and other under-served areas in Egypt. This may account for the long duration of prior symptoms. The usual symptoms and signs associated with IE are non-specific. Thus, unless the clinician maintains a high index of suspicion, diagnosis can be missed. This long duration of symptoms prior to diagnosis may also have resulted in the high rates of complications and adverse outcomes. In a study of IE conducted in France [23], 25\% of patients were diagnosed late (>1 month after onset of symptoms) and this delay was associated with higher rates of surgical management.

HAE accounted for $46.5 \%$ of cases in this registry; 95 (51.4\%) of them had a history of predisposing procedure in the preceding 3 months. The most common was valve replacement surgery with associated early PVE (28.4\%) followed by intravenous lines (20\%). These findings are consistent with the 34\% reported by ICE-PCS [24] and with the global increase in medical procedures, devices and health care services.

The rate of culture-negative IE was high among our patients which complicates the ability to make definitive diagnosis. This may be attributed to the use of antibiotics for treatment of antecedent febrile illness prior to hospital admission and the drawing of blood cultures. In literature, the rate of culture-negative IE ranges between 2.5 and 31\% [25-28]. This rate was high in Algeria [29] (56.4\%) and South Africa [30] (55.3\%) compared to the UK [31] (12.2\%) and France [32] (9\%).

\section{Complications}

The overall complication rate was high (39.4\%), similar to other reports [19]. The main complications were potentially life-threatening, including HF, severe sepsis, and renal failure, which likely contributed to the high in-hospital mortality. Late diagnosis and the high incidence of the Staphylococcal species are contributing factors, in addition to the inability to perform surgery in some patients when indicated. A similar short-term mortality result (20\%) was reported in a previous meta-analysis [33]. Predictors of mortality have varied in different studies. In one study [34], the main predictors of higher mortality were chronic obstructive pulmonary disease, cerebral embolism, Staphylococcus, and gram-negative bacilli as well as surgical treatment when indicated. In a nation-wide survey in Japan [35], the main predictors of higher mortality were Staphylococcus aureus infection and
HF while early surgery was associated with a decrease in mortality.

\section{Temporal trends}

There were significant changes noted over the period of assessment. Comparing the findings from period 1 (the first 6 years) and period 2 (the following 5 years) showed a significant decrease in RHD as an underlying disease for IE with an increase in IVDU-associated IE, with predominance of Staphylococcal species as a causative organism. HAE and prior antibiotic use decreased significantly in period 2. However, the median duration of symptoms prior to diagnosis increased, highlighting the need for provider and patient education regarding risk factors, symptoms and signs of IE, and the importance of early diagnosis.

During the period of observation, there was also a substantial change in the types of causative organisms. Staphylococcal IE increased significantly in period 2 due to increased IVDU; and although the percent of IE cases with negative cultures also increased in the same period, identification of the causative organism improved significantly owing to the use of more sophisticated diagnostic methods like serologic tests and polymerase chain reaction (PCR) of histologic specimens. While these techniques were used routinely in period 2, they were restricted in period 1 to situations of clinical suspicion of zoonotic infection in the presence of negative blood cultures. Similar findings were reported in a study conducted in Algeria [29] where the application of serologic tests and PCR techniques decreased the proportion of IE patients with unidentified organisms from 56.4 to $30.9 \%$; while in France [32], this rate dropped from 9 to $5 \%$. Thus, these techniques are important tools to enhance pathogen identification. However, these techniques are expensive and not readily available in all clinical settings, limiting their routine use in the country.

\section{Limitations}

This study was conducted at a tertiary care facility involving high numbers of referred patients and with the availability of sophisticated diagnostic and therapeutic capabilities [36-42], leading to selection and referral bias, and creating difficulty in generalizability of the findings [43-45]. Population-based studies-that may provide better information-are few and have their own limitations as well [46]. Thus, our study as well as similar studies from tertiary care centers likely includes severe and complicated cases. In addition, the more developed diagnostic and therapeutic capabilities at our center may also have favorably impacted the outcomes of the patients. 


\section{Conclusions}

This study is the first to describe the clinical features, microbiological characteristics, and outcome of patients with IE admitted to a tertiary care facility in Egypt over 11 years. High rates of culture-negative IE, IVDU, complications, and mortality as well as the young age of the patients and long duration of symptoms prior to diagnosis were the most prominent features.

Over the period of observation, there were improvements noted in the detection of the causative organisms and in outcomes, including rates of complications and mortality in the second period.

Despite this progress, IE remains a serious and deadly disease. A third of patients experienced a serious complication, and a fifth died during their hospitalization. Further efforts are needed to disseminate information regarding the risk factors for IE, to educate providers on early diagnosis and to continue to expand access to preventive, diagnostic, and therapeutic interventions in the country.

\section{Additional file}

Additional file 1: Microbiology methods. (DOCX $33 \mathrm{~kb}$ )

\begin{abstract}
Abbreviations
Euro-ENDO registry: European Infective Endocarditis registry; HAE: Healthcare associated IE; HF: Heart failure; ICD: Implantable cardioverter defibrillator; ICE-PCS: International Collaboration on Endocarditis Prospective Cohort Study; IE: Infective endocarditis; IQR: Interquartile range; IVDU: Intravenous drug use; PCR: Polymerase chain reaction; PVE: Prosthetic valve endocarditis; RHD: Rheumatic heart disease; SD: Standard deviation; TTE: Transthoracic echocardiography
\end{abstract}

\section{Authors' contributions}

$\mathrm{HHR}$ and KAS were the principal investigators with contributions on the level of supervision, auditing, and reviewing of difficult cases as well as arranging for seminars and workshops in addition to revision of the manuscript. AAE, GSY, and MSM were involved in diagnosis and management of patients, database entry, and revision as well as writing the manuscript. AS was involved in the diagnosis and management of patients. KS and HHK were involved in reviewing difficult cases and performing echocardiographic studies. MGE and AAE were responsible for laboratory workup. AE and ASA were responsible for performing cardiac surgeries for indicated patients. SMM was responsible for pathological examination of surgical specimens. All authors read and approved the final manuscript.

\section{Funding}

This research did not receive any specific grant from funding agencies in the public, commercial, or not-for-profit sectors.

\section{Availability of data and materials}

The datasets used and/or analyzed during the current study are available from the corresponding author on reasonable request.

\section{Ethics approval and consent to participate}

This research involved human subjects and was performed in accordance with the Declaration of Helsinki and approved by Cairo University Ethical Committee. A written informed consent was obtained from all patients.

\section{Consent for publication}

Not applicable.

\section{Competing interests}

The authors declare that they have no competing interests.

\section{Author details}

${ }^{1}$ Department of Cardiology, Kasr Al Aini Hospital, Faculty of Medicine, Cairo University, Cairo 11562, Egypt. ${ }^{2}$ Department of Cardiothoracic Surgery, Kasr Al Aini Hospital, Faculty of Medicine, Cairo University, Cairo 11562, Egypt. ${ }^{3}$ Department of Clinical Pathology and Microbiology, Kasr Al Aini Hospital, Faculty of Medicine, Cairo University, Cairo 11562, Egypt. ${ }^{4}$ Department of Pathology, Kasr Al Aini Hospital, Faculty of Medicine, Cairo University, Cairo 11562, Egypt.

Received: 22 July 2019 Accepted: 16 August 2019

Published online: 11 September 2019

References

1. Mylonakis E, Calderwood SB (2001) Infective endocarditis in adults. N. Engl. J. Med. 345:1318-1330. https://doi.org/10.1056/NEJMra010082

2. Prendergast BD (2006) The changing face of infective endocarditis, Heart. https://doi.org/10.1136/hrt.2005.067256

3. Moreillon P, Que Y-A (2004) Infective endocarditis. Lancet. 363:139-149. https://doi.org/10.1016/S0140-6736(03)15266-X

4. Fournier PE, Casalta JP, Habib G, Messana T, Raoult D (1996) Modification of the diagnostic criteria proposed by the duke endocarditis service to permit improved diagnosis of q fever endocarditis. Am. J. Med. 100:629-633. https://doi.org/10.1016/S0002-9343(96)00040-X

5. Horstkotte D, Follath F, Gutschik E, Lengyel M, Oto A, Pavie A, Soler-Soler J, Thiene G, Von Graevenitz A (2004) Guidelines on Prevention, diagnosis and treatment of infective endocarditis executive summary: The task force on infective endocarditis of the European Society of Cardiology. Eur. Heart J. 25:267-276. https://doi.org/10.1016/j.ehj.2003.11.008

6. Baddour LM, Wilson WR, Bayer AS, Fowler VG, Bolger AF, Levison ME, Ferrieri P, Gerber MA, Tani LY, Gewitz MH, Tong DC, Steckelberg JM, Baltimore RS, Shulman ST, Burns JC, Falace DA, Newburger JW, Pallasch TJ, Takahashi M, Taubert KA (2005) Infective endocarditis. Circulation 111. https://doi.org/1 0.1161/Circulationaha.105.165564

7. Bonow RO, Carabello BA, Chatterjee $K$, de Leon AC, Faxon DP, Freed MD, Gaasch WH, Lytle BW, Nishimura RA, O'Gara PT, O'Rourke RA, Otto CM, Shah PM, Shanewise JS (2008) 2008 Focused update incorporated into the ACC/ AHA 2006 guidelines for the management of patients with valvular heart disease: a report of the American College of Cardiology/American Heart Association Task Force on Practice Guidelines (Writing Committee to). Circulation. https://doi.org/10.1161/CIRCULATIONAHA.108.190748

8. Nishimura RA, Carabello BA, Faxon DP, Freed MD, Lytle BW, O'Gara PT, O'Rourke RA, Shah PM, Bonow RO, Chatterjee K, De Leon AC, Gaasch WH, Otto CM, Shanewise JS, Smith SC, Jacobs AK, Buller CE, Creager MA, Ettinger SM, Krumholz HM, Kushner FG, Page RL, Tarkington LG, Yancy CW (2008) ACC/AHA 2008 guideline update on valvular heart disease: focused update on infective endocarditis: a report of the American College of Cardiology/ American Heart Association Task Force on practice guidelines: Endorsed by the society of cardiovascular anest. Circulation 118:887-896. https://doi. org/10.1161/CIRCULATIONAHA.108.190377

9. Kearney P, Mokracek A, Butchart E, Hassager C, Uva MS, Miro JM, Danchin N, Lekakis J, Franzen D, Prendergast B, Selton-Suty C, Moritz A, Reiner Z, Thuny F, Vilacosta I, Muller L, Bongiorni MG, Auricchio A, Widimsky P, Vardas P, Gould K, Hall R, Thilen U, Ceconi C, Filippatos G, Aguilar R, Naber CK, McDonagh T, Delahaye F, Erbel R, van Camp G, Hobbs R, Lengyel M, Nihoyannopoulos P, de Jesus Antunes M, Sechtem U, Habib G, Calvar JASR, Tornos P, Borger M, Tendera M, Dean V, McGregor K, Funck-Brentano C, Zamorano JL, Vahanian A, Bax J, Popescu BA, Sirnes PA, Seferovic P, Moreillon P, Trinchero R, McManus R, Hoen B, Rosenhek R, Kjeldsen K, Tornos P, Thuny F, Prendergast B, Vilacosta I, Moreillon P, de Jesus Antunes M, Thilen U, Lekakis J, Lengyel M, Muller L, Naber CK, Nihoyannopoulos P, Moritz A, Zamorano JL, Vahanian A, Auricchio A, Bax J, Ceconi C, Dean V, Filippatos G, Funck-Brentano C, Hobbs R, Kearney P, McDonagh T, McGregor K, Popescu BA, Reiner Z, Sechtem U, Sirnes PA, Tendera M, Vardas P, Widimsky P, Vahanian A, Aguilar R, Bongiorni MG, Borger M, Butchart E, Danchin N, Delahaye F, Erbel R, Franzen D, Gould K, Hall R, Hassager C, Kjeldsen K, McManus R, Miro JM, Mokracek A, Rosenhek R, Calvar JASR, Seferovic P, Selton-Suty C, Uva MS, Trinchero R, van Camp G (2009) Guidelines on the prevention, diagnosis, and treatment of infective endocarditis (new version 2009): the task force on the prevention, diagnosis, 
and treatment of infective endocarditis of the European Society of Cardiology (ESC). Eur. Heart J 30:2369-2413. https://doi.org/10.1093/eurheartj/ehp285

10. Habib G, Lancellotti $P$, Antunes MJ, Bongiorni MG, Casalta J-P, Del Zotti F, Dulgheru R, El Khoury G, Erba PA, lung B, Miro JM, Mulder BJ, PlonskaGosciniak E, Price S, Roos-Hesselink J, Snygg-Martin U, Thuny F, Tornos Mas P, Vilacosta I, Zamorano JL, Erol Ç, Nihoyannopoulos P, Aboyans V, Agewall S, Athanassopoulos G, Aytekin S, Benzer W, Bueno H, Broekhuizen L, Carerj S, Cosyns B, De Backer J, De Bonis M, Dimopoulos K, Donal E, Drexel H, Flachskampf FA, Hall R, Halvorsen S, Hoen B, Kirchhof P, Lainscak M, LeiteMoreira AF, Lip GY, Mestres CA, Piepoli MF, Punjabi PP, Rapezzi C, Rosenhek R, Siebens K, Tamargo J, Walker DM, Zamorano JL, Aboyans V, Achenbach S, Agewall S, Badimon L, Barón-Esquivias G, Baumgartner H, Bax JJ, Bueno H, Carerj S, Dean V, Erol Ç, Fitzsimons D, Gaemperli O, Kirchhof P, Kolh P, Lancellotti P, Lip GY, Nihoyannopoulos P, Piepoli MF, Ponikowski P, Roffi M, Torbicki A, Vaz Carneiro A, Windecker S, Metzler B, Jahangirov T, Sudzhaeva S, Vanoverschelde J-L, Macic-Džankovic A, Donova T, Skoric B, Georgiou GC, Linhartova K, Bruun NE, Rizk H, Kõvask S, Jovanova S, Delahaye F, Petriashvili S, Naber CK, Hahalis G, Varga A, Hrafnkelsdóttir TJ, Shapira Y, Cecchi E, Kerimkulova A, Kamzola G, Jonkaitiene R, Wagner K, Demarco DC, Zarzur J, Aakhus S, Stepinska J, Gavina C, Vinereanu D, Paleev F, Obrenovic-Kircanski B, Hricák V, Thilén U, Kaufmann B, Bouma BJ, Baccar H, Ozer N, Gale CP, Nesukay E (2015) 2015 ESC Guidelines for the management of infective endocarditis. Eur. Heart J. 36:3075-3128. https://doi.org/10.1093/eurheartj/ehv319

11. Baddour LM, Wilson WR, Bayer AS, Fowler VG, Tleyjeh IM, Rybak MJ, Barsic B, Lockhart PB, Gewitz MH, Levison ME, Bolger AF, Steckelberg JM, Baltimore RS, Fink AM, O'Gara P, Taubert KA (2015) Infective Endocarditis in adults: diagnosis, antimicrobial therapy, and management of complications. Circulation. 132:1435-1486. https://doi.org/10.1161/CIR.0000000000000296

12. Meshaal MS, Labib D, Said K, Hosny M, Hassan M, Al Aziz SA, Elkholy A, Anani M, Rizk H (2018) Aspergillus endocarditis: diagnostic criteria and predictors of outcome, a retrospective cohort study. PLoS One 13:e0201459. https://doi.org/10.1371/journal.pone.0201459

13. Meshaal MS, Kassem HH, Samir A, Zakaria A, Baghdady Y, Rizk HH (2015) Impact of routine cerebral ct angiography on treatment decisions in infective endocarditis. PLoS One. 10:e0118616. https://doi.org/10.1371/ journal.pone.0118616

14. Singer M, Alkady H, Mohsen T, Roushdy A, Akl A, Mashaal M (2017) Predictors of surgical outcome in isolated tricuspid valve endocarditis: single center experience of 60 patients. Thorac. Cardiovasc. Surg. 65:634638. https://doi.org/10.1055/s-0037-1606386

15. G.S. Youssef, M.S. Mashaal, D.R. El Remisy, K.A. Sorour, H.H. Rizk, Pericardial effusion in prosthetic and native valve infective endocarditis, Indian Heart J. (2019) 0-4. doi:https://doi.org/10.1016/j.ihj.2018.12.002.

16. Ammar W, El Aroussi W, El Mahy A, El Kholy A, Rizk H (2013) Case-control study of potential culprit procedures for infective endocarditis in an Egyptian tertiary care center. Egypt. Hear. J. 65:153-157. https://doi.org/10.1 016/j.ehj.2013.05.004

17. Al-Rachidi N, El-Kholy A, Elanany M, Soliman M, Hassan R, Bassiouny D, Rizk H (2018) Early diagnosis of infective endocarditis using a commercial multiplex PCR assay in Egypt. Kasr Al Ainy Med. J. 23:67. https://doi.org/1 0.4103/2356-8097.218997

18. El-Kholy AA, El-Rachidi NGE d, El-Enany MG, AbdulRahman EM, Mohamed RM, Rizk HH (2015) Impact of serology and molecular methods on improving the microbiologic diagnosis of infective endocarditis in Egypt. Infection 43:523-529. https://doi.org/10.1007/s15010-015-0761-2

19. Kanafani ZA, Mahfouz TH, Kanj SS (2002) Infective endocarditis at a tertiary care centre in Lebanon: Predominance of streptococcal infection. J. Infect. https://doi.org/10.1016/S0163-4453(02)91041-8

20. Nashmi A, Memish ZA (2007) Infective endocarditis at a tertiary care centre in Saudi Arabia: Review of 47 cases over 10 years. East. Mediterr. Heal. J. 13:64-71

21. Ferraris L, Milazzo L, Ricaboni D, Mazzali C, Orlando G, Rizzardini G, Cicardi M, Raimondi F, Tocalli L, Cialfi A, Vanelli P, Galli M, Antona C, Antinori S (2013) Profile of infective endocarditis observed from 2003-2010 in a single center in Italy. BMC Infect. Dis. https://doi.org/10.1186/1471-2334-13-545

22. Zhu W, Zhang Q, Zhang J (2017) The changing epidemiology and clinical features of infective endocarditis: A retrospective study of 196 episodes in a teaching hospital in China. BMC Cardiovasc. Disord. https://doi.org/10.1186/ s12872-017-0548-8

23. N'Guyen Y, Duval X, Revest M, Saada M, Erpelding M-L, Selton-Suty C, Bouchiat C, Delahaye F, Chirouze C, Alla F, Strady C, Hoen B (2017) Time interval between infective endocarditis first symptoms and diagnosis: relationship to infective endocarditis characteristics, microorganisms and prognosis. Ann. Med 49:117-125. https:/doi.org/10.1080/07853890.2016.1235282

24. Benito N, Miro JM, De Lazzari E, Cabell CH, Del Rio A, Altclas J, Commerford P, Delahaye F, Dragulescu S, Giamarellou H, Habib G, Kamarulzaman A, Kumar AS, Nacinovich FM, Suter F, Tribouilloy C, Venugopal K, Moreno A, Fowler VG (2009) Health care-associated native valve endocarditis: Importance of non-nosocomial acquisition. Ann. Intern. Med. https://doi. org/10.7326/0003-4819-150-9-200905050-00004

25. Albrich WC, Kraft C, Fisk T, Albrecht H (2004) A mechanic with a bad valve: Blood-culture-negative endocarditis. Lancet Infect. Dis. https://doi.org/10.1 016/S1473-3099(04)01226-5

26. Houpikian P, Raoult D (2005) Blood culture-negative endocarditis in a reference center: Etiologic diagnosis of 348 cases. Medicine (Baltimore). https://doi.org/10.1097/01.md.0000165658.82869.17

27. Millar B, Moore J, Mallon P, Xu J, Crowe M, Mcclurg R, Raoult D, Earle J, Hone R, Murphy P (2001) Molecular diagnosis of infective endocarditis - A new Duke's Criterion. Scand. J. Infect. Dis. https://doi.org/10.1080/00365540110026764

28. Naber CK, Erbel R (2007) Infective endocarditis with negative blood cultures. Int. J. Antimicrob. Agents. https://doi.org/10.1016/j.ijantimicag.2007.07.017

29. Benslimani A, Fenollar F, Lepidi H, Raoult D (2005) Bacterial zoonoses and infective endocarditis, Algeria. Emerg. Infect. Dis. https://doi.org/1 0.3201/eid1102.040668

30. Koegelenberg CFN, Doubell AF, Orth H, Reuter H (2003) Infective endocarditis in the Western Cape Province of South Africa: A three-year prospective study, QJM - Mon. J. Assoc. Physicians. https://doi.org/10.1093/ qjmed/hcg028

31. Lamas CC (2003) Blood culture negative endocarditis: analysis of 63 cases presenting over 25 years. Heart. https://doi.org/10.1136/heart.89.3.258

32. Hoen B, Alla F, Selton-Suty C, Béguinot I, Bouvet A, Briançon S, Casalta JP, Danchin N, Delahaye F, Etienne J, Le Moing V, Leport C, Mainardi JL, Ruimy R, Vandenesch F (2002) Changing profile of infective endocarditis: Results of a 1year survey in France. J. Am. Med. Assoc. https://doi.org/10.1001/jama.288.1.75

33. Abegaz TM, Bhagavathula AS, Gebreyohannes EA, Mekonnen AB, Abebe TB (2017) Short- and long-term outcomes in infective endocarditis patients: a systematic review and meta-analysis. BMC Cardiovasc. Disord. 17:291. https://doi.org/10.1186/s12872-017-0729-5

34. Ilhão Moreira R, Coutinho Cruz M, Moura Branco L, Galrinho A, Coutinho Miranda L, Fragata J, Cruz Ferreira R (2018) Infective endocarditis: Surgical management and prognostic predictors. Rev. Port. Cardiol. https://doi.org/1 0.1016/j.repc.2017.08.007

35. Ohara T, Nakatani S, Kokubo Y, Yamamoto H, Mitsutake K, Hanai S (2013) Clinical predictors of in-hospital death and early surgery for infective endocarditis: results of cardiac disease REGISTRATION (CADRE), a nation-wide survey in Japan. Int. J. Cardiol. https://doi.org/10.1016/j.jicard.2012.06.117

36. Murdoch DR, Corey GR, Hoen B, Miró JM, Fowler VG, Bayer AS, Karchmer AW, Olaison L, Pappas PA, Moreillon P, Chambers ST, Chu VH, Falcó V, Holland DJ, Jones P, Klein JL, Raymond NJ, Read KM, Tripodi MF, Utili R, Wang A, Woods CW, Cabell CH, International Collaboration on EndocarditisProspective Cohort Study (ICE-PCS) Investigators, T.I. Investigators (2009) Clinical presentation, etiology, and outcome of infective endocarditis in the 21st century: the International Collaboration on Endocarditis-Prospective Cohort Study. Arch. Intern. Med 169:463-473. https://doi.org/10.1001/ archinternmed.2008.603

37. Thuny F, Avierinos J-F, Habib G (2010) Changing patterns in epidemiological profiles and prevention strategies in infective endocarditis: from teeth to healthcare-related infection. Eur. Heart J. 31:1826-1827. https://doi.org/10.1 093/eurheartj/ehq154

38. López J, Revilla A, Vilacosta I, Sevilla T, Villacorta E, Sarriá C, Pozo E, Rollán MJ, Gómez I, Mota P, San Román JA (2010) Age-dependent profile of leftsided infective endocarditis: a 3-center experience. Circulation. https://doi. org/10.1161/CIRCULATIONAHA.109.877365

39. Chirouze C, Athan E, Alla F, Chu VH, Ralph Corey G, Selton-Suty C, Erpelding M-L, Miro JM, Olaison L, Hoen B (2013) Enterococcal endocarditis in the beginning of the 21st century: analysis from the International Collaboration on Endocarditis-Prospective Cohort Study. Clin. Microbiol. Infect. 19:11401147. https://doi.org/10.1111/1469-0691.12166

40. Fowler VG, Miro JM, Hoen B, Cabell CH, Abrutyn E, Rubinstein E, Corey GR, Spelman D, Bradley SF, Barsic B, Pappas PA, Anstrom KJ, Wray D, Fortes CQ, Anguera I, Athan E, Jones P, Van Der Meer JTM, Elliott TSJ, Levine DP, Bayer AS (2005) Staphylococcus aureus endocarditis: a consequence of medical progress. J. Am. Med. Assoc. https://doi.org/10.1001/jama.293.24.3012 
41. Cabell CH, Jollis JG, Peterson GE, Corey GR, Anderson DJ, Sexton DJ, Woods CW, Reller LB, Ryan T, Fowler VG (2002) Changing patient characteristics and the effect on mortality in endocarditis. Arch. Intern. Med. 162:90. https://doi. org/10.1001/archinte.162.1.90

42. Sevilla T, López J, Gómez I, Vilacosta I, Sarriá C, García-Granja PE, Olmos C, Di Stefano S, Maroto L, San Román JA (2017) Evolution of prognosis in leftsided infective endocarditis: a propensity score analysis of 2 decades. J. Am. Coll. Cardiol. 69:111-112. https://doi.org/10.1016/J.JACC.2016.10.052

43. Fernández-Hidalgo N, Almirante B (2012) Infective endocarditis in the XXI century: Epidemiological, therapeutic, and prognosis changes. Enferm. Infecc. Microbiol. Clin. 30:394-406. https://doi.org/10.1016/j.eimc.2011.11.005

44. Kanafani ZA, Kanj SS, Cabell CH, Cecchi E, Ramos ADO, Lejko-Zupanc T, Pappas PA, Giamerellou H, Gordon D, Michelet C, Muñoz P, Pachirat O, Peterson G, Tan RS, Tattevin P, Thomas V, Wang A, Wiesbauer F, Sexton DJ (2010) Revisiting the effect of referral bias on the clinical spectrum of infective endocarditis in adults. Eur. J. Clin. Microbiol. Infect. Dis. https://doi. org/10.1007/s10096-010-0983-2

45. Slipczuk L, Codolosa JN, Davila CD, Romero-Corral A, Yun J, Pressman GS, Figueredo VM (2013) Infective endocarditis epidemiology over five decades: a systematic review. PLoS One. 8:e82665. https://doi.org/10.13 71/journal.pone.0082665

46. Tleyjeh IM, Abdel-Latif A, Rahbi H, Scott CG, Bailey KR, Steckelberg JM, Wilson WR, Baddour LM (2007) A systematic review of population- based studies of infective endocarditis. Chest. 132:1025-1035. https://doi.org/10.13 78/chest.06-2048

\section{Publisher's Note}

Springer Nature remains neutral with regard to jurisdictional claims in published maps and institutional affiliations.

\section{Submit your manuscript to a SpringerOpen ${ }^{\circ}$ journal and benefit from:}

- Convenient online submission

- Rigorous peer review

- Open access: articles freely available online

- High visibility within the field

- Retaining the copyright to your article

Submit your next manuscript at $\boldsymbol{\nabla}$ springeropen.com 